\title{
AT V DULGHIERU: ACCOUNTING FOR THE PROFITS OF SEX TRAFFICKING
}

\author{
Anne O'Driscoll
}

This article explores the remedies available to victims of the international crime of trafficking in persons for sexual exploitation. In the 2009 case of AT v Dulghieru (Dulghieru), the English High Court awarded the victims of an unlawful conspiracy to traffic general, aggravated and exemplary damages. Treacy J based the exemplary award on the rationale of preventing unjust enrichment. The appropriateness of the finding of unlawful means conspiracy is considered, as are each of the damages awards. This article concludes that the prevention of unjust enrichment is an inappropriate basis for an award of exemplary damages, and argues that the better approach would be to strip a defendant's gains by the equitable remedy of account of profit. The overlap of civil remedies and the criminal law is also addressed. It is proposed that an account of profit should take priority over any criminal confiscation order as the victims have a greater entitlement to the profits than the State does.

\section{INTRODUCTION}

Trafficking in persons for sexual exploitation generates an estimated annual profit of US\$27.8 billion worldwide. ${ }^{1}$ Traffickers make their profits at the cost of severe physical and psychological injury to their victims. The United Nations has described the conduct as "one of the most egregious violations of human rights". ${ }^{2}$ New Zealand has criminalised human trafficking in accordance with its international obligations. ${ }^{3}$ However, what remedies are available to trafficking victims remains

* $\quad$ Submitted as part of the LLB(Hons) programme at Victoria University of Wellington. Recipient of the 2009 Robert Orr McGechan Prize. I would like to thank my supervisor, Geoff McLay, for his invaluable assistance.

1 Patrick Belser Forced Labour and Human Trafficking: Estimating the Profits (2005, International Labour Organisation, Working Paper) at 15.

2 Forward to the United Nations Convention against Transnational Organized Crime (opened for signature 12-15 December 2000, entered into force 29 September 2003).

3 See Crimes Act 1961, ss 98B-98E. See also United Nations Convention against Transnational Organized Crime, ibid, and the supplementary Protocol to Prevent, Suppress and Punish Trafficking in Persons, Especially Women and Children (opened for signature 12 to 15 December 2000, entered into force 28 Jan 2004). 
unclear. The close relationship between traffickers' high profits and the victims' physical and psychological suffering creates unique difficulties in determining an appropriate remedy.

In AT v Dulghieru, four women sued their traffickers in tort, alleging they were victims of an unlawful conspiracy to traffic them for sexual exploitation. The women were told they would find work in England as dancers but were instead forced into prostitution, falsely imprisoned and subjected to threats of significant violence. The English High Court accepted the claims and awarded each claimant general, aggravated and exemplary damages. ${ }^{4}$ Treacy $\mathrm{J}$ justified the exemplary award as "necessary to prevent unjust enrichment". 5 This article submits that the prevention of unjust enrichment is an inappropriate basis for an exemplary award. The proper focus of exemplary damages is on the quality of a defendant's conduct, not on the profits made. The principle against unjust enrichment may, however, allow the court to disgorge a trafficker's gains through the equitable remedy of account of profit.

Both defendants had been previously convicted of criminal offences for sex trafficking and subjected to long periods of imprisonment and confiscation orders. The imposition of civil remedies thus raises additional considerations of double punishment and double counting. Exemplary damages are generally inappropriate where a defendant has already been punished in the criminal law. Disgorgement is not subject to objections of double punishment but double counting is still an issue. Confiscation orders and account of profit relate largely to the same funds. This article argues that the overlap should not prevent an award of account of profit. Even where criminal confiscation orders are a possibility, a victim's entitlement to disgorge a trafficker's gains by way of account of profit should take priority.

\section{AN UNLAWFUL CONSPIRACY TO TRAFFIC}

The claimants alleged they were victims of an unlawful conspiracy to traffic them into the United Kingdom for the purposes of sexual exploitation. ${ }^{6}$ The particulars of their claim included false representation, false imprisonment, sexual battery, assault, and harassment. ${ }^{7}$ Treacy $\mathrm{J}$ accepted each claim without any explicit reasoning, ${ }^{8}$ possibly due to the defendants' failure to appear or to defend the case. The nature of the torts relied on and the interests they protect are nevertheless important to determining the remedies available.

AT, NT, ML, AKv Gavril Dulghieru and Tamara Dulghieru (Dulghieru) [2009] EWHC 225 (QB).

$5 \quad$ Ibid, at [68] and [71].

6 Ibid, at [3].

7 Ibid.

8 Ibid, at [12]. 


\section{A Factual Background}

The defendants induced the claimants to enter the United Kingdom by representations that they would find work as dancers. In reality, the defendants intended to sexually enslave them. ${ }^{9}$ In England, the defendants kept the claimants locked in a basement flat. ${ }^{10}$ They threatened the claimants and their families with serious violence if they failed to co-operate when dealing with immigration authorities. ${ }^{11}$ From the basement flat, the claimants were taken to various brothels and forced to prostitute themselves in order to repay a $£ 20,000$ bond and $£ 300$ a day rent. ${ }^{12}$ Treacy $\mathrm{J}$ accepted that the sexual encounters took place "without the consent of the Claimants whose upset, distress and reluctance was made all too plain but was cruelly and harshly overridden by the perverted greed of their captors who sought only to use them as instruments for their own profit". ${ }^{13}$

\section{B Unlawful Means Conspiracy}

Unlawful means conspiracy involves an agreement between two or more people to use "unlawful means" to cause harm. ${ }^{14}$ The House of Lords has held that 'unlawful means' includes both torts and criminal conduct, ${ }^{15}$ and must thus include the statutory offence of trafficking. ${ }^{16}$ The primary purpose of the defendant's actions need not be the intention to cause injury but the conduct must be "the means of intentionally inflicting harm rather than ... merely incidental to it". ${ }^{17}$ In Dulghieru, a court would be justified in finding that the conspiracy to traffic constituted the means of intentionally inflicting harm on the claimants. It is no defence to conspiracy to claim that the primary purpose is to further one's own interests if the flipside of the defendant's gain is the plaintiff's loss. However, unlawful means conspiracy is an economic tort. ${ }^{18}$ Economic torts are actionable only on proof of actual pecuniary damage. ${ }^{19}$ To satisfy a pecuniary loss requirement, the claimants would need to conceptualise their injury as loss of potential earnings and quantifiable

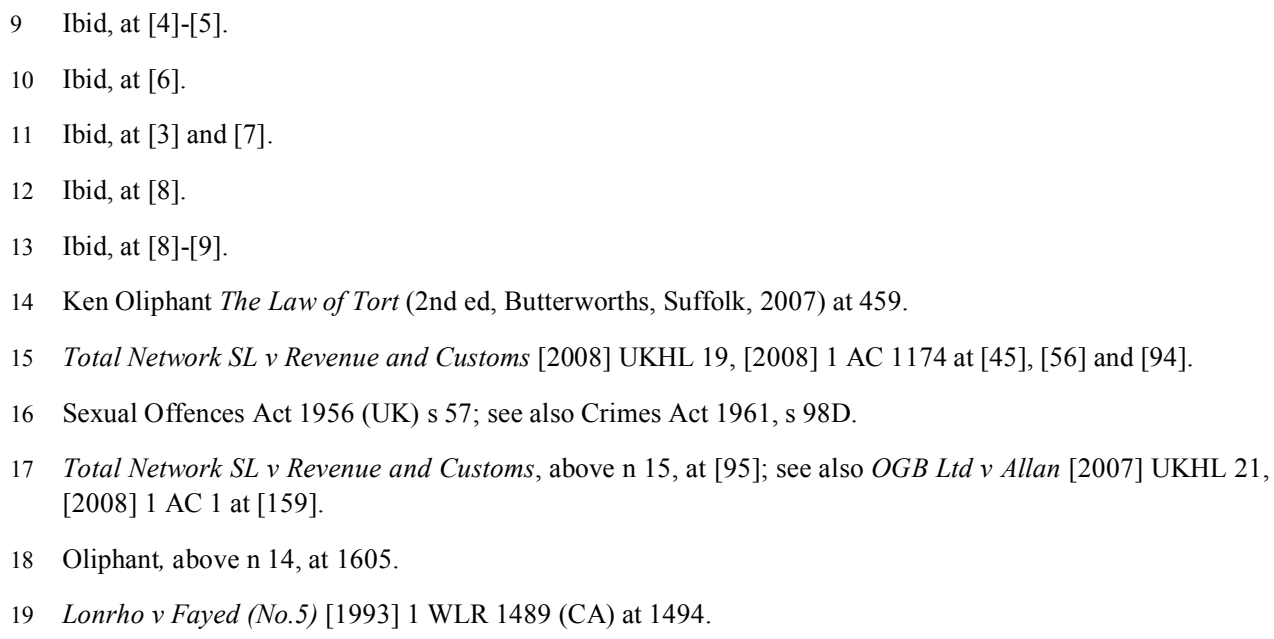


medical expenses. The substantial physical and psychological harm suffered is not the flipside of the defendant's gain. Arguably, pecuniary loss is unnecessary where the unlawful means are also torts which are actionable against at least one of the defendants in their own right. ${ }^{20}$ If so, the claimants could claim unlawful conspiracy without proof of economic harm based on the torts in the particulars of claim but not on the criminal offence. This distinction has not yet been developed in the case law.

\section{The Particulars of Claim}

The particulars of the conspiracy were false representation, false imprisonment, sexual battery, assault and harassment. False representation gives rise to an action in deceit because the claimants detrimentally relied on the defendants' fraudulent representations. ${ }^{21}$ False imprisonment is made out as the claimants were physically confined in the basement. ${ }^{22}$ The sexual battery claim is less straightforward. Battery involves the intentional application of unlawful force to another without their consent. ${ }^{23}$ Reluctant acquiescence may qualify as consent in the absence of actual threats or undue influence. ${ }^{24}$ On one view, the claimants in Dulghieru could be taken to have legally consented to the sexual encounters, induced by the circumstances of the trafficking and the pressure to repay the $£ 20,000$ bond and the $£ 300.00$ a day rent. Canadian courts have recognised a distinction between exploitation cases and cases involving physical battery. ${ }^{25}$ In Norberg $v$ Wynrib, a doctor supplied a woman with restricted drugs in return for sexual favours. ${ }^{26}$ The majority of the Supreme Court of Canada indicated that the notion of consent might be modified to appreciate the power relationship between the parties. ${ }^{27}$ The majority found that the "unequal power and exploitative nature of the relationship removed the possibility of the appellant's providing meaningful consent to the sexual contact". ${ }^{28}$ Norberg may be borderline, but few would argue that the claimants in Dulghieru were capable of providing "meaningful consent" in light of the exploitative relationship. Assault is an intentional act which creates a reasonable apprehension of an imminent battery upon

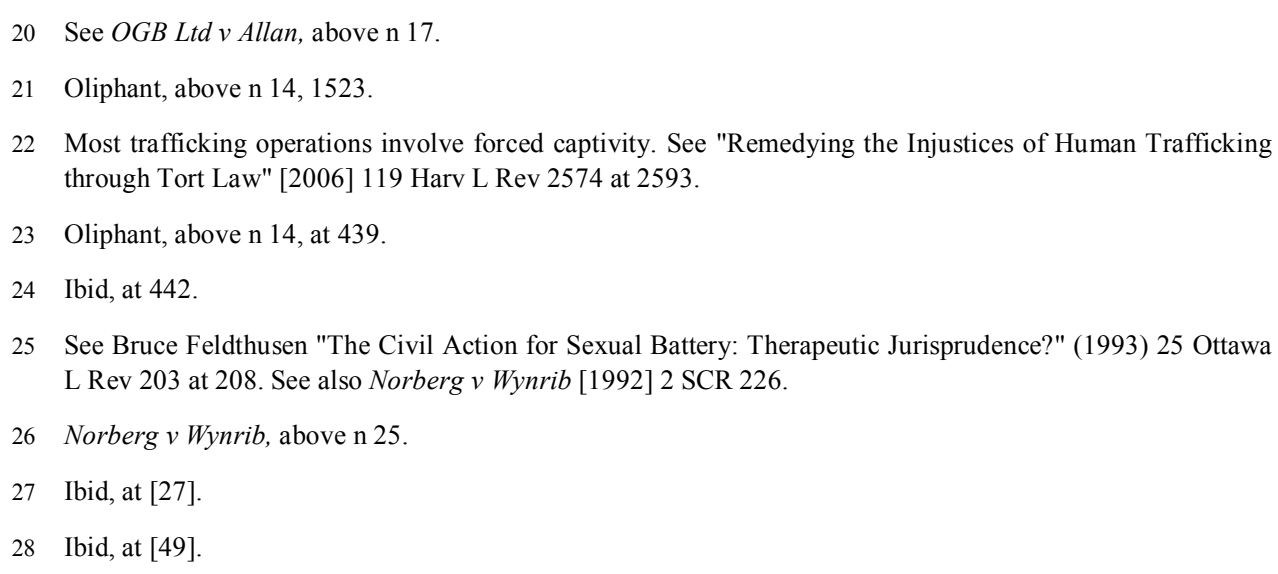


another. ${ }^{29}$ The threat need not be immediate. ${ }^{30}$ The defendants' control over the claimants and the threats of violence support the assault claim. The last claim of harassment is a statutory tort. ${ }^{31}$ Conduct amounts to harassment if a reasonable person in possession of the same information would think it amounted to harassment. ${ }^{32}$ A reasonable person would be likely to consider the atmosphere of fear and control maintained by the defendant as harassment.

\section{COMPENSATION FOR VICTIMS OF HUMAN TRAFFICKING}

In England, trafficked persons may seek compensation for their injuries and losses through a compensation order during the criminal proceedings, by application to the Criminal Injuries Compensation Authority and through civil litigation. ${ }^{33}$ In New Zealand, the primary avenue of compensation would be under the Accident Compensation Act 2001. Where injury is covered by the accident compensation scheme, civil compensation and criminal reparations are barred. State funded compensation is the most appropriate means of ensuring that a victim is compensated for their injuries as it does not depend on the means or conviction of an offender. One issue with state funded compensation is that it relieves defendants of their liability to compensate victims. With the exception of aggravated damages, compensation does not take into account the conduct of the defendant and no form of compensation takes into account a defendant's gains as a result of their wrongdoing.

\section{A The Compensatory Award in Dulghieru}

Treacy J awarded the claimants both general and aggravated damages. Each award takes account of different factors and compensates different injury. A court must take care to ensure that the claimant does not recover twice for the same injury and that the total amount does not exceed fair compensation.

\section{General damages for pain, suffering and loss of amenity}

Treacy J approached the award for pain, suffering and loss of amenity "globally" by looking at the post traumatic stress disorder, the coerced sexual activity and the false imprisonment together. ${ }^{34}$ Allowing for differences between the individual cases, he awarded the claimants AT $£ 125,000$, NT

29 Oliphant, above n 14 , at 455.

30 Smith v Chief Superintendent, Woking Police Station (1983) 76 Cr App Rep 234 (QB).

31 Protection from Harassment Act 1997 (UK).

32 Ibid, s 1(2)

33 Janice Lam and Klara Skrivankova, Opportunities and Obstacles: Ensuring access to compensation for trafficked persons in the UK (October 2008, Anti-Slavery International, Working Paper) at 7.

34 Dulghieru, above n 4, at [41]. 
$£ 117,000$, ML $£ 82,000$ and $\mathrm{AK} £ 97,000$ in general damages respectively. ${ }^{35}$ Each claimant was diagnosed with chronic post traumatic stress disorder, but allowance was made for differences in the severity of the disorder, ${ }^{36}$ and in the periods of false imprisonment. ${ }^{37}$

\section{Aggravated damages}

Aggravated damages serve to compensate a complainant for injury to feelings, including humiliation, loss of pride and dignity and feelings of anger or resentment, caused or increased by the manner in which the defendant committed the wrong or his or her subsequent behaviour. ${ }^{38}$ Aggravated damages are compensatory in nature but may take into account the defendants' motives and conduct where they aggravate the injury to the plaintiff. Treacy $J$ awarded $£ 35,000$ to AT and $\mathrm{ML}$, and $£ 30,000$ to NT and AK in aggravated damages. The difference in amount took into account that the latter two did not face the prospect of giving evidence at the criminal trial. Treacy $\mathrm{J}$ found that the defendants' "insulting and arrogant treatment of the claimants, trampling, as it did, upon their rights as autonomous human beings" warranted a substantial award of aggravated damages. He considered that the general damages award would not adequately compensate the injury to the claimants' human pride and dignity, and their humiliation, distress, degradation and insult. ${ }^{39}$ In New Zealand, circumstances of aggravation tend to be treated as factors justifying an increase in compensatory damages rather than a distinct category of damages. ${ }^{40}$ As aggravated damages are compensatory in nature, they are also barred in respect of covered personal injury.

\section{State funded compensation}

In England, the Criminal Injuries Compensation Authority (CICA) may provide victims of crime with lump sum compensation, compensation for loss of earnings and for "special expenses" up to a maximum overall sum of $£ 500,000 .{ }^{41}$ AT, NT and AK each received CICA compensation and ML was awaiting a decision on her application. CICA compensation does not affect the right to sue but any CICA award must be repaid in full up to the amount of any other remedy subsequently

35 Ibid, at [51].

36 AT fell into the "moderately severe" category while the others fell into the "moderate" category: Dulghieru, above $\mathrm{n}$, at [43]-[44] and [51].

37 AT, NT and AK were falsely imprisoned for approximately two months. ML was only imprisoned for one month: Dulghieru, above n 4, at [43]-[44] and [51].

38 Dulghieru, above n 4, at [57].

39 Ibid, at [62].

40 See Attorney-General v Niania [1994] 3 NZLR 106, at 111 (HC) per Tipping J. See also Midland Metals Overseas Pte Ltd v Christchurch Press Co Ltd [2002] 2 NZLR 289 (CA) per Tipping J.

41 Criminal Injuries Compensation Act 1995 (UK), ss 1-6. See also Criminal Injuries Compensation Scheme 2008, at [23]. 
received in respect of the same injury. ${ }^{42}$ This prevents double recovery while preventing the defendant from placing any weight on a payment which he did not make. It is unclear whether the reimbursement requirement would apply in respect of any subsequent exemplary or gain-based award.

In New Zealand, the primary avenue of compensation is under the state funded accident compensation scheme. Where personal injury is covered by the Accident Compensation Act 2001, damages arising directly or indirectly out of that injury are barred. ${ }^{43}$ The bar extends to all compensatory damages including aggravated damages. ${ }^{44}$ "Personal injury" includes both physical and mental injury. ${ }^{45}$ However, a mental injury is only covered if it amounts to a clinically significant behavioural, cognitive, or psychological dysfunction, ${ }^{46}$ and is "a result of" physical injury or one of the sexual offences listed in Schedule 3.47 "[A] result of" is interpreted to require a direct causal link. ${ }^{48}$

The Act probably covers the claimants' injury. Post traumatic stress disorder falls within the definition of mental injury. ${ }^{49}$ Trafficking is not a schedule offence but a court could find a direct causal link between the claimants' disorder and their physical injury. While there is tension under the Act as to when mental injury is covered by the Act, the facts of Dulghieru are analogous to those in Woodd $v$ ACC. In Woodd $v A C C$, the District Court allowed cover for the mental injury of a woman who also suffered bruising and bilateral shoulder pain after having a gun held to her head and being forcibly held, pushed around and tied up. ${ }^{50}$ Cadenhead $\mathrm{J}$ considered it artificial to sever the physical injuries from the matrix of fact making up the assault and found the physical injuries to be a "very definite causative aspect" of the mental injury. ${ }^{51}$ He drew a distinction between cases of mere assault unaccompanied by physical injury and cases involving violence and the infliction of

\footnotetext{
42 Criminal Injuries Compensation Scheme 2008, at [49].

43 Accident Compensation Act 2001, s 317(7).

44 Donselaar v Donselaar [1982] 1 NZLR 97 (CA).

45 Accident Compensation Act 2001, s 27.

46 Ibid.

47 Ibid, s 26 (definition of personal injury), s 21 (cover for mental injury caused by certain criminal acts) and sch 3 (cover for mental injury caused by certain acts dealt with in Crimes Act 1961).

48 ACC v Geerders DC Wellington 188/04, 8 July 2004

49 See Woodd v ACC DC Wellington AI288/02, 2 April 2003; Greenland-Tangipo v ACC DC Wellington AI539/01, 6 March 2003.

50 Woodd $v A C C$, ibid.

51 Ibid.
} 
physical injury. ${ }^{52}$ In Sivasubramaniam v Yarrall, the High Court limited Woodd to its facts, holding that mental injury caused by a source other than physical injury is not covered by the Act where that other source is more than a de minimis cause. ${ }^{53}$ The plaintiff, who suffered physical injury, the death of her unborn child and mental injury as a result of a car accident, could thus sue in tort for mental injury arising out of a car accident generally. ${ }^{54}$ On the facts of Dulghieru, it would seem artificial to sever the physical assaults from the trauma suffered. Cover would also be consistent with the policy of the Act of compensating victims for mental injury caused by sexual offences. However, to the extent that false imprisonment and the "atmosphere of fear and control" maintained by the assault and harassment caused distress, humiliation and fear, compensatory damages may still be available in tort. In Willis $v$ Attorney-General, the Court of Appeal held that the legislative bar did not preclude claims for compensatory damages in false imprisonment, even where the injury qualifies as personal injury. ${ }^{55}$

\section{Criminal compensation orders and reparation payments}

In England, criminal courts have the power to make compensation orders against convicted offenders of up to $£ 5,000$ to go to the victim. ${ }^{56}$ Criminal compensation orders do not prevent the victim claiming civil damages in excess of this award or equal to it if they fail to recover through the criminal court. There is no evidence of any compensation ordered against the defendants in the prior criminal proceedings. In New Zealand, there is a strong statutory presumption in favour of reparation. ${ }^{57}$ Criminal courts may order reparation for any emotional harm caused by the offender including clinical conditions such as traumatic stress disorders. ${ }^{58}$ However, where the victim is entitled to compensation under the accident compensation scheme, the victim may not claim reparation in respect of that injury, not even to top up ACC entitlements to provide full recovery. ${ }^{59}$ Where the victim may seek compensation through any other avenue, the court must take this into

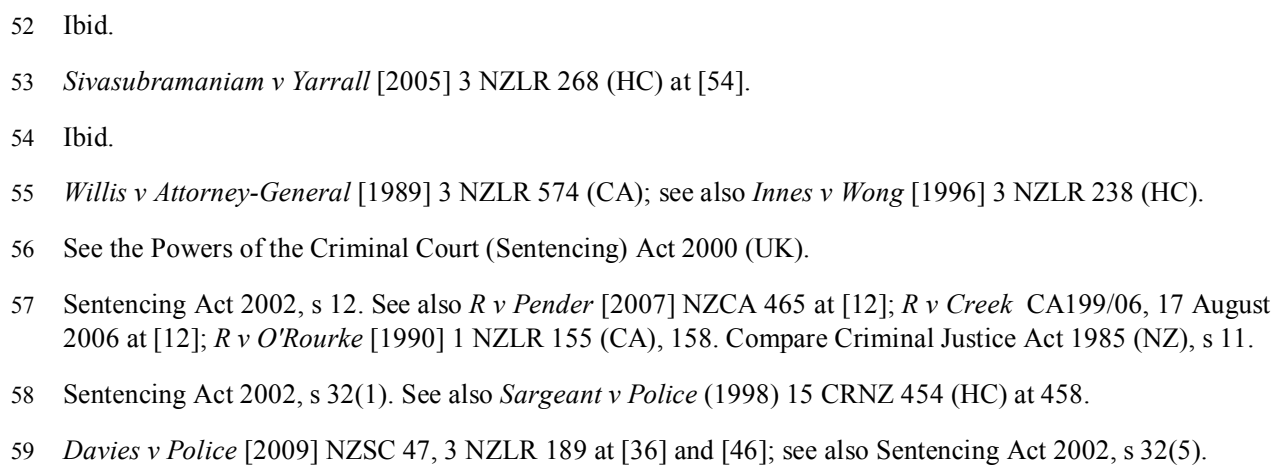


account but it does not preclude reparation. ${ }^{60}$ The amount of any criminal reparation may need to be deducted from the civil damages the plaintiff would otherwise receive. ${ }^{61}$

\section{EXEMPLARY DAMAGES AND UNJUST ENRICHMENT}

Treacy $\mathrm{J}$ awarded a further $£ 60,000$ as exemplary damages against the Dulghierus to be divided equally between the four claimants. He justified the exemplary award as "primarily one of preventing unjust enrichment". ${ }^{62}$ The principle of preventing unjust enrichment in this context is concerned with stripping the defendant of gains made by a wrong. ${ }^{63}$ The desire to strip the defendants of the profits made by forcing the claimants into prostitution is understandable and intuitively appealing. The defendants deliberately disregarded the claimants' rights with a view to making a profit beyond anything able to be subsequently recovered by way of legal process. They were also confident that, by their use of coercion and threats, they "would never face any financial reckoning" at the hands of the claimants. ${ }^{64}$ However, the purpose of exemplary damages is not to disgorge a defendant's profits but to punish, deter and denounce the defendant's behaviour.

In England, the traditional formulation of the purpose of exemplary damages is "to punish and deter" ${ }^{65}$ While there is some English authority for the view that the prevention of unjust enrichment may justify an exemplary award where the defendant has profited from their wrongdoing, this approach confuses the goals of deterrence and preventing unjust enrichment. The rationale of deterrence is to "teach a wrongdoer that tort does not pay". ${ }^{66}$ Prevention of unjust enrichment is only concerned with disgorging gains that do not belong to the defendant in good conscience. ${ }^{67}$ This is an important distinction. In New Zealand, it is reasonably settled that punishment is the main purpose of exemplary damages. Deterrence is recognised as a distinct purpose of exemplary damages but is subordinate to the punitive rationale. Where conduct is calculated to make a profit, deterrence gains significance but the overriding punitive rationale limits the award to the amount necessary to punish the defendant.

60 Sentencing Act 2002, s 32(3).

61 Stephen Todd, The Law of Torts in New Zealand (5th ed, Brookers, Wellington, 2009) 89.

62 Dulghieru, above n 4, at [75].

63 See Halifax Building Society v Thomas [1996] Ch 217 (CA). See generally Peter Birks An Introduction to the Law of Restitution (Clarendon Press, Oxford, 1989) at 23-24, 40-44, 313-315 and 346-355.

64 Dulghieru, above n 4, at [70].

65 See Rookes v Barnard [1964] AC 1129 (HL) at 1221; see also Harvey McGregor McGregor on Damages (16th ed, Street and Maxwell Ltd, London, 1997) at 287.

66 Rookes v Barnard, ibid, at 1227; see also Taylor v Beere [1982] 1 NZLR 81 (CA) at 88-89 and 96.

67 See Allan Beever, "The Structure of Aggravated and Exemplary Damages" (2003) 23 Oxford Journal of Legal Studies 87 at 100 . 


\section{A England: The Categories Test}

Exemplary damages are available only in the three categories laid down by Lord Devlin in Rookes $v$ Barnard. The first concerns "oppressive, arbitrary or unconstitutional action by the servants of the government". ${ }^{68}$ The second allows exemplary damages where the defendant has calculated that his conduct will make a profit which "may well exceed the compensation payable to the plaintiff". ${ }^{69}$ The third provides for express authorisation of exemplary damages by statute. Treacy $\mathrm{J}$ found that the facts of Dulghieru fitted within the category of exemplary damages dealing with cynical breaches calculated to make a profit. ${ }^{70}$ In Rookes $v$ Barnard, however, Lord Devlin did not consider that "in matters criminal an aggrieved party should be given an option to inflict for his own benefit punishment by a method which denies the offender the protection of the criminal law". ${ }^{71}$ His Lordship did not contemplate that exemplary damages would be available for "assaults" as these "can generally be punished as crimes". ${ }^{72}$ As the defendants were punished for criminal offences arising out of the same facts, the defendants' conduct fits uneasily within Lord Devlin's category of profit-motivated wrongs.

A number of restrictions further limit the availability of exemplary damages, even where the facts fall within one of the three categories. A court may award exemplary damages "if, but only if" compensatory damages would be inadequate to punish the defendant, deter others, and mark the court's disapproval of such conduct. ${ }^{73}$ The plaintiff must be the victim of the punishable behaviour. In Archer $v$ Brown, the courts specifically ruled out the availability of exemplary damages where the claimants have been criminally punished based on the principle that "a man should not be punished twice for the same offence". ${ }^{74}$ Even if the facts of Dulghieru satisfy the categories test, it is unclear whether the "if, but only if" threshold test is met and whether exemplary damages are appropriate given the substantial punishment in the criminal proceedings.

\section{$B$ Is the Rationale of Exemplary Damages the "Prevention of Unjust Enrichment"?}

In Borders (UK) Ltd v Commissioner of Police of the Metropolis, the English Court of Appeal awarded exemplary damages against a street trader who made an estimated annual profit of over

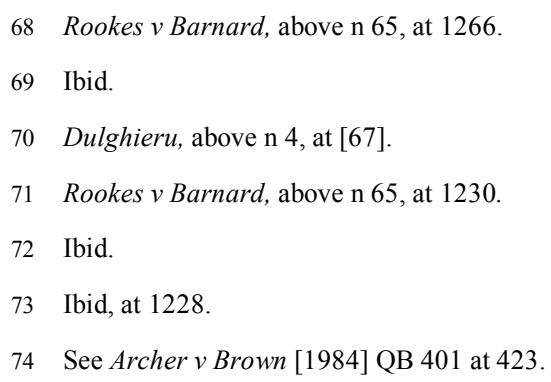


$£ 300,000$ by organising the theft and sale of some 250,000 books. $^{75}$ The Court of Appeal explicitly concluded that the "real purpose" of exemplary damages where wrongdoing is calculated to make a profit "is not the punishment of the defendant but the prevention of his unjust enrichment". ${ }^{76}$ The Court of Appeal relied heavily on Lord Diplock's comments in Broome v Cassell ${ }^{77}$ and Lord Scott's speech in $\mathrm{Kuddus}^{78}$ in support of its conclusion. However, the effect of the decision was an expansion of exemplary damages, which was inconsistent with the reasoning in the cited authority.

\section{Broome v Cassell}

In Broome v Cassell, the House of Lords upheld an exemplary award of $£ 25,000$ against a defendant who published a false and deliberately controversial account of a war time naval disaster libellous of the plaintiff. ${ }^{79}$ Lord Diplock described the category of exemplary damages for profit motivated wrongs as "analogous to the civil law concept of enrichessement indue", ${ }^{80}$ and held that an award to strip at least a defendant's profits is necessary to protect the rights the law purports to confer. However, his Lordship acknowledged it was a "blunt instrument to prevent unjust enrichment" not restricted to the defendants' actual gains as this might "leave a defendant contemplating an unlawful act with the certainty that he had nothing to lose to balance against the chance that the plaintiff might never sue him or, if he did, might fail in the hazards of litigation". 81 Lord Diplock's judgement illustrates only that the deterrent rationale of exemplary damages may in some circumstances lead to the elimination of the defendants' gains, not that disgorgement is the purpose of exemplary damages.

The other Lords emphasised a deterrent rationale more explicitly. Lord Hailsham focussed on the need to "teach the defendant and others that 'tort does not pay"'. ${ }^{82}$ Lord Hailsham emphasised that the calculation aspect was "not intended to be limited to the kind of mathematical calculations to be found on a balance sheet". ${ }^{83}$ Publishing a knowingly defamatory book because it was worth the risk of facing defamation proceedings and having to pay damages was held to be sufficient calculation. ${ }^{84}$ It is enough that a defendant anticipates that he may materially gain because any

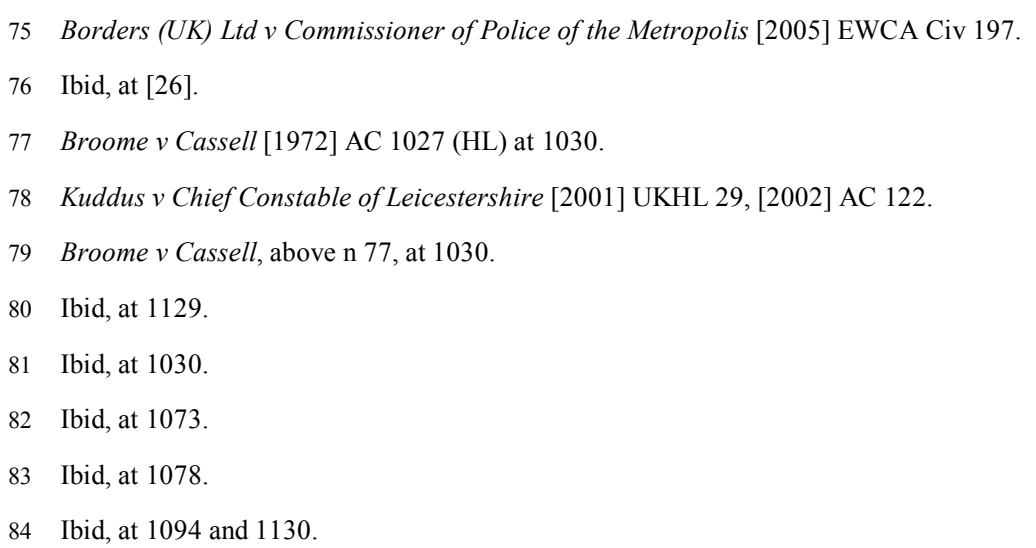


damages payable are exceeded by the defendant's gains or because the prospects of enforcement are slight. Lord Hailsham noted the possibility that a "defendant may calculate that the plaintiff will not sue at all because he has not the money ... or because he may be physically or otherwise intimidated". ${ }^{85}$ The decisive criterion was that "the tortious act must be done with guilty knowledge for the motive that the chances of economic advantage outweigh the chances of economic, or perhaps physical, penalty". ${ }^{86}$

The focus on motive and "calculation" speaks against an unjust enrichment approach. The essence of Broome is that exemplary damages should serve to deter wrongdoing by ensuring that a cost-benefit analysis will result in the conclusion that the wrongdoing is not worthwhile. The amount of profit may provide a guideline as to the size of the exemplary damages award but is not determinative. Deterrence may require more or less than the actual profit depending a range of factors. It may also be appropriate to base the award on the intended gains where they exceed those actually achieved ${ }^{87}$ The purpose of the award is to influence the behaviour of all potential actors, not simply to disgorge profits. Any elimination of profits is an incidental effect.

\section{Kuddus v Chief Constable of Leicester (Kuddus)}

In Kuddus, Lord Scott thought exemplary damages were in general an illegitimate remedy which offended the "fundamental principle of damages" to compensate for loss, but accepted there was a need for non-compensatory awards in cases where a defendant has committed a wrong with a view to material gain. ${ }^{88}$ His Lordship thought such awards would be more appropriately left to "restitutionary damages". ${ }^{89}$ Lord Scott's view supports the abolishment of exemplary damages, not the expansion of exemplary damages to prevent unjust enrichment. Lord Nicholls also indicated that the deterrence achieved through exemplary damages for profit motivated wrongs might be achieved by the less objectionable tool of disgorgement. ${ }^{90}$ His Lordship noted there was no logical reason why exemplary damages should be available for profit motivated wrongs and not other outrageous conduct. ${ }^{91}$ The decision in Kuddus may support recognition of a gain-based remedy for unlawful conspiracy but it cannot support the expansion of exemplary damages to include the rationale of unjust enrichment.

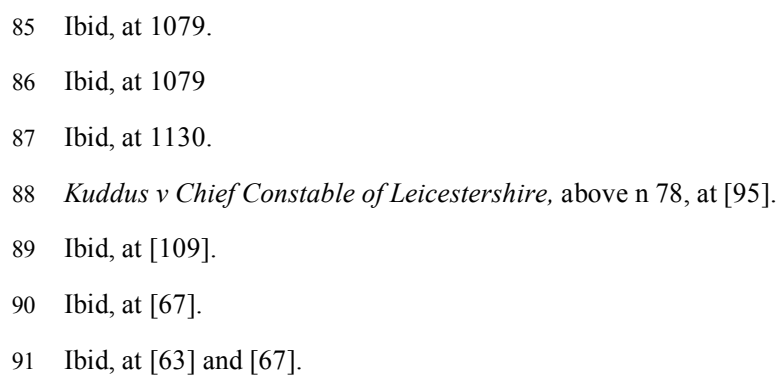




\section{New Zealand: the "Outrageousness" Standard}

New Zealand courts have refused to follow Rookes $v$ Barnard. ${ }^{92}$ Exemplary damages remain available for all torts wherever the defendant's conduct is "truly outrageous", 93 even in cases of personal injury covered by the accident compensation scheme. ${ }^{94}$ Outrageous conduct typically involves "conscious wrongdoing in contumelious disregard of another's rights". ${ }^{95}$ The law is now reasonably settled that punishment is the primary objective. ${ }^{96}$ The focus of the award is on the quality of the defendant's conduct. ${ }^{97}$ The Court of Appeal in $A v$ Bottrill held that it was "both too late and inconsistent with the evolution of exemplary damages in New Zealand ... to change the focus and emphasise a general deterrence rationale". ${ }^{98}$ Richardson $\mathrm{P}$ thought that deterrence could be "achieved as a consequence of the appropriate punishment of the wrongdoer". 99

\section{Guiding principles: punishment and moderation.}

Punishment must be proportional to the gravity of the conduct deserving of punishment. ${ }^{100}$ The New Zealand courts also emphasise moderation. The Court of Appeal has stated that the "marking out and punishment of outrageous behaviour can be adequately achieved by a relatively modest punitive penalty". ${ }^{101}$ New Zealand's focus on punishment and moderation acts as a restraint on the size of awards, so exemplary damages are generally lower in New Zealand than in other jurisdictions. $^{102}$

92 Taylor v Beere [1982] 1 NZLR 81 (CA) at 92.

93 Ellison $v L$ [1998] 1 NZLR 416 (CA) at 419.

94 Accident Compensation Act 2001, s 319(1).

95 See Taylor v Beere, above n 92, at 93.

$96 A v$ Bottrill [2002] UKPC 44, [2003] 2 NZLR 721 (PC). Daniels $v$ Thompson [1998] 3 NZLR 22 at 29; $W v$ $W$ [1999] 2 NZLR 1 at 2 (PC). See generally Forest Miller "Exemplary Damages" in Peter Blanchard (ed) Civil Remedies in New Zealand, (Brookers Ltd, Wellington, 2003) 525 at 533.

97 Taylor v Beere, above n 92, at 92.

98 Bottrill $v A$ [2001] 3 NZLR 622 (CA) at [42].

99 Ibid.

100 Ellison v L, above n 93; McLaren Transport Ltd v Somerville [1996] 3 NZLR 424 (HC). See also Bruce Feldthusen "Positive damages: Hard Choices and High Stakes" [1998] NZ Law Review 741 at 750.

101 Ellison $v$ L, above $\mathrm{n} 93$.

102 See John Y Gotanda "Punitive Damages: A Comparative Analysis" [2004] 42 Columbia Journal of Transnational Law 391 at 418. 


\section{Where wrongdoing is calculated to profit}

The highest awards have been in the defamation cases involving wrongdoing for profit. The principle against unjust enrichment is neither the reason nor a justification for the discrepancy between the size of awards in personal injury cases and defamation cases. The differences in amount are largely explicable by the need for greater financial awards to effect deterrence where profit is involved. Excessive divergence may be due to the fact that defamation trials are typically by jury whereas other civil actions are typically determined by a trial judge. ${ }^{103}$ English courts have attempted to curb the disparity between awards in defamation and awards in personal injury cases by including comparisons between them in jury instructions. ${ }^{104}$

Some high awards in defamation cases can only be explained by an exception to the moderation principle and a shift from a punitive to a deterrent rationale. In Television NZ Ltd v Quinn, the New Zealand Court of Appeal upheld a global jury verdict of $\$ 400,000$ against the defendants for deliberately making allegations, which they knew they could not prove, to increase or maintain ratings. ${ }^{105}$ Cooke $\mathrm{P}$ considered that calculation for profit is one factor in considering exemplary damages and included the need to "deter the defendant and others from defaming people" as part of the rationale. ${ }^{106}$ His Honour was reluctant to require juries to be "moderate", preferring an indication that they "should not be carried away". ${ }^{107}$ The decision demonstrates the occasional use of exemplary damages to eliminate a defendant's gains but the award was not strictly limited to the actual profits made. The appropriateness and level of exemplary damages still depended on whether the conduct in question "called for punishment". 108

\section{Exemplary damages and accident compensation}

The courts may also consider the windfall to the plaintiff and the wealth of the defendant. ${ }^{109}$ The bar on compensatory damages exacerbates the difficulties in assessing quantum. Exemplary damages are meant to be a "top up", available only where other remedies are inadequate to punish the defendant and to mark the court's disapproval. In personal injury cases, exemplary awards stand alone. There is a perception that the legal profession and the courts "have sought and provided

103 See Stephen Todd "Exemplary Damages" (1998) 18 NZULR 145 at 194.

104 John v MGN Ltd [1997] QB 586 at 615-616.

105 Television New Zealand v Quinn [1996] 3 NZLR 24 (CA).

106 Ibid, at 37.

107 Ibid.

108 Ibid, at 37 and 46-47.

109 See Joanna Manning "Reflections on Punitive Damages and Personal Injury in New Zealand" (2002) 2 NZ Law Review 143. 
alternative remedies by way of punitive damages for victims". ${ }^{110}$ The Court of Appeal has stressed that immoderate awards should be discouraged and that the courts need to keep a "tight rein" on claims "with a view to countering any temptation, conscious or unconscious, to give exemplary damages merely because the statutory benefits may be felt to be inadequate". ${ }^{11}$ The Court of Appeal has rejected any compensatory goal for exemplary damages. ${ }^{112}$ The injury to the plaintiff is only relevant to the extent it illustrates the outrageousness of the defendant's conduct. ${ }^{113}$ Any attempt to justify an exemplary award on the principle of unjust enrichment would be likely to have the effect of circumventing the bar.

\section{Relevance of Prior Criminal Conviction}

The courts will also take into account any prior punishment. In Daniels $v$ Thompson, a case involving four separate appeals relating to sexual battery actions, the Court of Appeal held that either conviction or acquittal in a prior criminal proceeding prevented any subsequent recovery of exemplary damages. ${ }^{114}$ Where there has been no concluded prosecution, an exemplary damages claim is permitted but may be stayed as long as prosecution remains likely. ${ }^{115}$ Parliament modified the rule in Daniels $v$ Thompson to allow exemplary damages claims in respect of covered personal injury despite previous conviction or sentence. ${ }^{116}$ As a result, the availability of exemplary damages in New Zealand turns on whether the conduct corresponds to a criminal offence, whether the injury is personal injury under the Act and the likelihood of criminal proceedings. As the defendants in Dulghieru had been criminally punished, the claimants would only be entitled to claim exemplary damages in respect of personal injury covered by the Act. Daniels $v$ Thompson would bar any exemplary damages claim in respect of the false imprisonment claim and any personal injury not covered by the Act. In Part III, it was submitted that the claimants' post traumatic stress disorder would be likely to be covered by the Act.

\section{ACCOUNT OF PROFIT AND UNLAWFUL MEANS CONSPIRACY}

The equitable remedy of account of profit may be a more appropriate approach to stripping human traffickers of their profits. In the classic English statement on the purpose of account of profit, Slade J stated that "the purpose of ordering an account of profit in favour of a successful

110 Auckland District Law Society Compensation for Rape and Other Assaults (Public Issues Committee, Auckland, 1998).

111 Donselaar v Donselaar, above n 44, at 107.

112 Daniels $v$ Thompson [1998] 3 NZLR 22 at 28-29.

113 See Todd, above n 103, at 188 .

114 Daniels $v$ Thompson, above $\mathrm{n} 112$, at 46-50.

115 Ibid.

116 Accident Insurance Act 1998, s 396, now Accident Compensation Act 2001, s 319. 
plaintiff ... is to prevent an unjust enrichment of the defendant". ${ }^{117}$ It is generally accepted that the law may in some cases award a remedy based on a defendant's gains rather than a plaintiff's losses. The defendants' enrichment is "unjust" in the sense of being made "by doing wrong to the plaintiff". ${ }^{118}$ Unjust enrichment by wrongdoing is analytically distinct from "unjust enrichment by subtraction", which is concerned with reversing legally invalid transfers of wealth made "at the expense of the plaintiff". ${ }^{119}$ Disgorgement may be an appropriate remedy even where the plaintiff suffers no compensable loss.

\section{A A Principled Basis for Account of Profit in Tort}

The concept of unjust enrichment alone is insufficient to justify a departure from the presumption of compensation in tort. ${ }^{120}$ The maxim that "a person not be allowed to profit from their wrong" is too general to justify the general availability of a gain-based remedy in all circumstances or provide any clear guidance as to when an account of profit may be appropriate. ${ }^{121}$ There is no general consensus as to when disgorgement is appropriate.

\section{A legitimate interest in preventing the defendant's profit-making activity}

In Attorney-General v Blake the House of Lords held that the Crown was entitled to recover Blake's royalties from his publication in breach of a contractual undertaking not to divulge official information gained as a result of his employment. ${ }^{122}$ The majority accepted the availability, at least in exceptional cases, of gain-based remedies for breach of contract. ${ }^{123}$ Lord Nicholls rejected the notion that damages must always be awarded to compensate loss, accepting that damages may be measured by reference to the benefit obtained by the wrongdoer "when the circumstances require". ${ }^{124}$ His Lordship considered that account of profit would be available where other remedies were "inadequate", where it is "the most appropriate remedy" or where it is "just and equitable that the defendant should retain no benefit from his breach of contract". ${ }^{125}$ The decision offers no fixed rules to determining the appropriateness of a gain-based remedy for breach of contract but indicates

\footnotetext{
117 My Kinda Town Ltd v Soll [1982] FSR 147 (Ch) at 156.

118 See Sarah Worthington "Reconsidering disgorgement for wrongs" (1999) 62 MLR 218 at 220.

119 Andrew Burrows Remedies for Torts and Breach of Contract (3rd ed, Oxford University Press, Oxford, 2004) at 371

120 See Beever, above n 67.

121 Attorney General (UK) v Times Newspaper Ltd (No 2) [1990] 1 AC 109 (HL) at 286.

122 Attorney General v Blake [2001] 1 AC 268 (HL).

123 Ibid, at 284-285.

124 Ibid, at 285.

125 Ibid.
} 
that all the circumstances of the contract and breach are relevant. ${ }^{126}$ Lord Nicholls provides that a "useful general guide, although not exhaustive, is whether the plaintiff had a legitimate interest in preventing the defendant's profit-making activity and, hence, in depriving him of his profit". ${ }^{127}$ The claimants in Dulghieru have a greater interest than the Crown in Blake in preventing the defendant's profit making activity, because the profit making activity violated their human rights.

\section{Nature of the protected interest}

Account of profit is a well-established remedy for fiduciary duties and duties of confidence. Disgorgement is also common for breaches of intellectual property torts, ${ }^{128}$ and other property rights, such as conversion, trespass to goods and trespass to land. ${ }^{129}$ In the United States, a party who makes a profit from a fraudulent misrepresentation may be required to disgorge any profit made from a fraudulent representation. ${ }^{130}$ The purpose of fiduciary obligations and property rights is to ensure the beneficiary has exclusive use and benefit of the property or other right. ${ }^{131}$ Rights to the exclusive use and benefit of property or confidential information can only be fully protected by stripping the defendants of the gains made in breach of them. There is an argument that account of profit in the context of property rights and fiduciary obligations serve to compensate the plaintiff's lost opportunity to bargain with the defendant for a fee for the use of the property or other right. ${ }^{132}$ Rather than extend the remedy of account of profit, some suggest that it would be more appropriate to reconsider the rules for the assessment of compensation. ${ }^{133}$ This argument fails to take into account cases where plaintiffs would not have surrendered the right at any price or where the plaintiff could not have made that gain. ${ }^{134}$ In Dulghieru, the claimants would not have surrendered their right to the inviolability of their person at any price.

126 Ibid.

127 Ibid.

128 Copyright, Designs and Patents Act 1988 (UK), s 96(2) (infringement of copyright), s 279(2) (infringement of design right), s 61 (infringement of performer's property right); see also Patents Act 1977 (UK), s $61(1)(d)$.

129 AM Honoré "Ownership" in AG Guest (ed) Oxford Essays in Jurisprudence (Oxford University Press, Oxford, 1961) at 116-117.

130 See Lan v Giraudo 40 NE (2d) 707 (1942 SCM) 711; Janigan v Taylor 433 F (2d) 781 (1965 CA $1^{\text {st }}$ Cir) 786. See generally James Edelman "Unjust Enrichment, Restitution and Wrongs" [2001] Texas Law Review 1869.

131 See Peter Jaffey "Restitutionary Damages and Disgorgement" [1995] RLR 30, at 35.

132 Robert Sharpe and Stephen Waddams "Damages for lost opportunity to bargain" (1982) 2 OJLS 290. See also Francesco Giglio "Restitution for Wrongs: A Structural Analysis" (2007) 20 CJLJ 5 at 11.

133 See Cash Handling Systems Ltd v Augustus Terrace Developments Ltd (1996) 2 NZ Conv C 192 at 398.

134 Worthington, above n 118, at 223-224. 
In England, disgorgement has sometimes been effected under the label of "money had and received". ${ }^{135}$ The tort of deceit should give rise to a right to prevent a defendant's gains from their fraud. The traditional view was that a gain-based remedy was only available where the defendant's gain consisted of the plaintiff's property or the proceeds of that property. ${ }^{136}$ There is, however, no clear reason in logic or principle why account of profit should be available for trespass to land and goods but not for trespass to the person. If a defendant profits at the expense of the victim's person, that should come with just as much entitlement to any proceeds thereof. In Norberg, a minority of the Supreme Court of Canada preferred to deal with a sexual exploitation case between a doctor and patient as a breach of fiduciary duty and suggested that "sexual exploitation" might be more appropriately viewed as a separate cause of action to other sexual battery. ${ }^{137}$ While Dulghieru does not involve such a fiduciary relationship, the claimants' reliance on the defendants' false representations and the power imbalance in the relationship make Norberg a useful analogy. In Blake, the House of Lords was willing to award the Crown an account of profit for a breach of contractual obligation because it was "closely akin to a fiduciary obligation". ${ }^{138}$ The relationship between the traffickers and victims in Dulghieru is arguably analogous to the relationship in Norberg and the exploitation is more extreme. The analogy indicates that account of profit may be an appropriate remedy for sexual battery in the context of the case.

\section{Corrective justice}

Competing with the maxim that a man should not be allowed to profit from his wrong is a general reluctance to make a claimant better off as a result of the award than he was prior to the wrong. ${ }^{139}$ As the defendant's unjust enrichment to be disgorged need not correspond to any loss experienced by the plaintiff, the remedy can deliver a windfall to the plaintiff. ${ }^{140}$ The windfall may be justified by the underlying rationale of the duty breached. Such is the case for the fiduciary duty of loyalty where the central function of the duty is to prevent profit taking. ${ }^{141}$ Alternatively, disgorgement may be justifiable by corrective justice concerns. Central to corrective justice theory is the relationship between the parties which singles out and connects them to an injustice. ${ }^{142}$ While

\footnotetext{
135 Ketlewell v Refuge Assurance Company [1908] 1 KB 545 (CA).

136 Phillips $v$ Homfray (1883) 24 Ch D 439 at 455.

137 Norberg $v$ Wynrib, above n 25, at 400. See also KMvH M [1992] 3 SCR 6.

138 Attorney General v Blake, above n 122, at 400.

139 See Peter Cane Anatomy of Tort Law (Hart Publishing, Oxford, 1997) at 113.

140 See Worthington, above n 118, at 220.

141 See Bristol and West Building Soc v Matthew [1998] Ch 1 (CA).

142 See Ernest Weinrib "Restitutionary Damages as Corrective Justice" (2000) Theoretical Inquiries in Law 6.
} 
exemplary damages focus on the defendant's conduct, ${ }^{143}$ disgorgement transfers the wrongdoer's gains to the victim who is entitled to them because of the "detriment" they suffered at the hands of the defendant, independent of any compensable loss. ${ }^{144}$ Where torts are actionable per se, the protected interests may be violated without loss. ${ }^{145}$ The wrongdoer's enrichment through such a wrong can be said to be "detrimental" to the victim based on the relationship between the parties as agent and victim of a wrong. The wrongdoer secures a gain specifically through a wrong of which the claimant is the victim. ${ }^{146}$ The conspiracy in Dulghieru involved the commission of the torts of false imprisonment, battery, assault and harassment. Each tort is a trespass to the person, actionable without proof of actual loss. Where a person profits from trespass to a person, the profits cannot in good conscience belong to the defendant. The person with the strongest interests in the profits is the victim.

\section{Cynical breach}

The English Law Commission considers that the courts should be willing to go to "the less extreme lengths of awarding restitution" to strip profits and deter cynical and wilful wrongdoing wherever exemplary damages would be available. ${ }^{147}$ The Court of Appeal in Blake rejected a "cynical breach" approach based on a deterrent rationale. ${ }^{148}$ In the House of Lords, Lord Nicholls agreed that the cynical nature of the breach would not itself justify a disgorgement remedy. ${ }^{149} \mathrm{~A}$ deterrent rationale would involve too great an overlap with exemplary damages, particularly in England. It would also fail to explain the availability of account of profit for breaches of fiduciary obligations and proprietary torts, which do not depend on the breach being dishonest, in bad faith or cynical. ${ }^{150}$ Of course, a cynical breach approach would clearly entitle the claimants in Dulghieru to the profits of the unlawful conspiracy to traffic them.

143 See Giglio, above n 132, at 22.

144 Ibid, at 24.

145 Ibid.

146 John Coleman Risks and Wrongs (Cambridge University Press, Cambridge, 1992) at 370-371.

147 Law Commission (England and Wales) Aggravated, Exemplary and Restitutionary Damages (Consultation Paper 132, 1993), at para 1.25. See also Edelman Gain-based Damages: Contract, Tort, Equity and Intellectual Property (Hart Publishing, Oxford, 2002) at 83 and 145.

148 Attorney General v Blake [1998] Ch 439 (CA) at 457.

149 Attorney General v Blake, above n 122, at 286.

150 See Law Commission (England and Wales), above n 147, at 31. See also Regal (Hastings) Ltd v Gulliver [1967] 2 AC 134 (HL). 


\section{B Account of Profit and Damages}

Disgorgement is a much less indeterminate remedy than exemplary damages. ${ }^{151}$ While there is no inherent limit on the quantum of the enrichment flowing from the wrong, the causal link between the profit and the wrongdoing provides a strong guide. Some consider that account of profit is too cumbersome based on a perception that it requires a very precise calculation of the relevant profits. ${ }^{152}$ In My Kinda Town Ltd $v$ Soll, Slade J stated that the intention of the court in awarding an account of profit is "to achieve a fair apportionment, so that neither party will have what justly belongs to the other". ${ }^{153}$ Account of profit need not strip away all the gains made by the wrongdoer. In Blake, Lord Nicholls commented that, "despite the niceties and formalities once associated with taking an account, the amount payable under an account of profit need not be any more elaborately or precisely calculated than damages". ${ }^{154}$ A complicating factor is the unresolved question of the consistency of account of profit with other awards.

In Tiny Intelligence Ltd $v$ Resport Ltd, the Supreme Court of New Zealand affirmed "the longstanding principle that damages and an account of profit cannot be obtained for the same wrongful act". ${ }^{155}$ This general principle has not been without its exceptions and there are strong arguments in favour of the compatibility of account of profit and other civil remedies in some circumstances. In Stevens $v$ Premium Real Estate, a case involving a breach of the duty of loyalty by a real estate agent, the majority of the Supreme Court indicated that account of profit and compensation are mutually exclusive remedies. ${ }^{156}$ Tipping J, however, identified a distinction between "remedies which are truly alternative and remedies which can properly be regarded as cumulative". ${ }^{157}$ In Personal Representatives of Tang Man Sit v Capacious Investments Ltd, the Privy Council held that an account of profit for breach of fiduciary duty to assign the claimant land was incompatible with damages for loss of use and occupation but acknowledged that account of profit and damages might be compatible in the "unlikely event that in the particular case the remedies are to some extent not inconsistent". ${ }^{158}$ Tipping $\mathrm{J}$ thought a proper distinction would turn in each case on the "seriousness of the wrong" and the "degree of moral turpitude" of the defendant. ${ }^{159}$ Moral turpitude may justify

151 Ross Granthan and Charles Rickett "Restitutionary Remedies" in Peter Blanchard (ed) Civil Remedies in New Zealand (Brookers Ltd, Wellington, 2003) 363 at 383.

152 See Burrows, above n 119, at 304.

153 My Kinda Town Ltd v Soll, above n 117, at 159.

154 Attorney General v Blake, above n 122, at 288.

155 Tiny Intelligence Ltd v Resport Ltd [2009] NZSC 35, [2009] 2 NZLR 581 at [22].

156 Stevens v Premium Real Estate Ltd [2009] NZSC 15, [2009] 2 NZLR 384 at [12] and [90].

157 Ibid, at [100].

158 Personal Representatives of Tang Man Sit v Capacious Investments Ltd [1996] 1 AC 514 at 520.

159 Stevens v Premium Real Estate Ltd, above n 156, at [104]. 
an exemplary award in addition to account but it is difficult to see how it justifies a compensatory award. Another distinction might be drawn between cases involving breaches of rights, where the claimant's loss is strictly linked to the defendant's benefit, and cases where there is no direct correlation between the defendant's gain and the plaintiff's loss. In general, financial gains made in tort will be accompanied by associated financial losses by the plaintiff. In cases where the defendant's gain is matched by an equivalent loss to the plaintiff, mutual exclusivity is justified by the risk of double-counting and double-recovery. In Dulghieru, the relevant injury was physical, psychological and emotional. The profit derived from the exploitation of their person and its disgorgement is based on corrective justice. The facts of Dulghieru may be the "unlikely event" contemplated in Tang Man Sit. If account of profit and damages are mutually exclusive, a claimant who suffers loss will have to bear some of the negative consequences of the wrong. ${ }^{160}$ It is unclear why the legal system should refuse to compensate an injured victim because of their entitlement to gains which have no correlation to their injury.

In Tiny Intelligence the Supreme Court denied the claimants "additional damages" for a flagrant copyright infringement because they had elected account of profit rather than compensation. ${ }^{161}$ The Supreme Court emphasised that "additional damages" and exemplary damages are parasitic on compensatory damages and unavailable in addition to account of profit. ${ }^{162}$ There is authority that indicates that an exemplary award may sometimes be appropriate to top up an account of profit. ${ }^{163}$ In Livingstone $v$ Rawyards Coal Company, the House of Lords awarded an appellant the market value of the coal which the respondent mined under the appellant's land, less the cost of removing the coal. ${ }^{164}$ While couched in compensatory language, the award is an example of an account of profit. All members of the House of Lords agreed that if there had been evidence of bad faith or sinister intention the appellant could have recovered the market value of the coal without allowing a deduction for the cost of working it. ${ }^{165}$ The refusal to allow a deduction would add a punitive element, recognised in Broome $v$ Cassell as an example of exemplary damages. ${ }^{166}$

\footnotetext{
160 See Giglio, above n 132, at 31-33.

161 Tiny Intelligence Ltd $v$ Resport Ltd, above n 155. See also Copyright Act 1994, s 121(2).

162 Ibid, at [32]

163 Livingstone v Rawyards Coal Company (1880) 5 App Cas 25 (HL); Bulli Coal Mining Co v Osborne [1899] AC 351 (PC).

164 Livingstone v Rawyards Coal Company, ibid.

165 Ibid.

166 Broome v Cassell, above n 77, at 1129.
} 


\section{THE CRIMINAL PROCEEDINGS}

Both Gavril and Tamara Dulghieru were convicted of criminal offences in relation to trafficking and subject to confiscation orders in the criminal proceedings totalling approximately $£ 786,000 .{ }^{167}$ Gavril Dulghieru was sentenced to nine years imprisonment for conspiring to traffic into prostitution, trafficking into the United Kingdom for sexual exploitation and plotting to facilitate unlawful immigration. Tamara Dulghieru was sentenced to five years imprisonment after being found guilty of immigration fraud, forgery and money-laundering offences but was cleared of trafficking for sexual exploitation. ${ }^{168}$ Relying on the justification of preventing unjust enrichment, Treacy $\mathrm{J}$ did not consider that either the imprisonment or the confiscation orders in the criminal proceedings precluded an award of exemplary damages.

In New Zealand, the penalty for the criminal offence of "trafficking in people by means of coercion or deception" is up to 20 years imprisonment, a fine up to $\$ 500,000$, or both. ${ }^{169}$ Human trafficking also falls within the definition of "significant criminal activity" in the Criminal Proceeds (Recovery) Act 2009. ${ }^{170}$ The High Court would thus be able to impose a profit forfeiture order if satisfied on the balance of probabilities that the respondent had unlawfully benefited from "significant criminal activity" and had interests in property. ${ }^{171}$

\section{Double punishment}

As the primary purpose of exemplary damages in New Zealand is punitive, there is at least a serious risk of double punishment where a defendant has been previously convicted. While exemplary damages may constitute a lesser punishment, their essentially punitive nature remains. ${ }^{172}$ The Court of Appeal held in Daniels $v$ Thompson that: "If the need to punish has already been met through the Court system, then the foundation of the 'right' [to exemplary damages] has been removed." 173 This conforms to the principle of the common law that no person shall be punished twice for the same cause, which has been described as "lying at the very foundation of human rights and privileges; a law of nature; and of obvious common sense and common justice". ${ }^{174}$ The adequacy of the criminal penalty is irrelevant; the double punishment theory extends to nominal

167 Dulghieru, above n 4, at [10]-[12].

168 Nigel Rosser "Asylum seeking couple jailed for trafficking women into sex trade" Evening Standard (London, 2 November 2005) at 16.

169 Crimes Act 1961, s 98D(2).

170 Criminal Proceeds (Recovery) Act 2009, s 6.

171 Criminal Proceeds (Recovery) Act 2009, s 55.

172 Todd, "Exemplary Damages", above n 103, at 171.

173 Daniels $v$ Thompson, above n 112, at 49.

174 Fay v Parker 52 NH 342 (SCNH 1873) at 389. 
penalties and discharge following conviction because it is up to the criminal court to determine the appropriate degree of punishment. ${ }^{175}$ There is a strong argument that the civil law has no role in prescribing damages where the legislature has developed its own scheme for the punishment of these wrongs. ${ }^{176}$ The Court of Appeal was persuaded by the undesirability of the court in its civil jurisdiction embarking upon an inquiry into the adequacy of the criminal penalty and the possibility of thereby undermining the criminal process.

Thomas J delivered a powerful dissent, opting for a "more cautious and less radical" discretionary approach. ${ }^{177}$ Even in Thomas J's dissenting view, criminal punishment is a powerful factor to be considered in the making of any additional exemplary award. However, thanks to his broader conception of the proper function of exemplary damages to include condemnation, education, vindication and appeasement of the victim, his Honour still thought they may be available in appropriate circumstances. ${ }^{178}$ Thomas $\mathrm{J}$ thought that criminal conviction should simply be one of the elements to be taken into account. Notably, "prevention of unjust enrichment" is missing from the list of the legitimate objectives of exemplary damages. ${ }^{179}$

The automatic bar on exemplary damages following criminal conviction flows from the punitive function of exemplary damages and is based on underlying principles of the common law against double jeopardy and double punishment. ${ }^{180}$ Account of profit overcomes these objections to double punishment because the purpose is to neutralise the defendant's gains and not to punish. While any award which strips the defendant's gains will have a punitive and deterrent effect, the overriding purpose is ensuring the defendant cannot retain property to which he or she has no right in equity.

\section{Proceeds of crime: double counting}

The maxim that no man should profit from his wrong is especially persuasive where the wrong is criminal. ${ }^{181}$ Many are of the opinion that the "enormity of the revenues derived from crime diminishes the deterrence capability of traditional criminal sanctions". ${ }^{182}$ Under proceeds of crime

175 Joanna Manning "Reflections on Exemplary Damages and Personal Injury Liability in New Zealand" (2002) 2 NZ Law Review 143 at 164.

176 See Chief Constable of Leicestershire v M [1989] 1 WLR 20 (Ch) at 23; Halifax Building Society v Thomas, above $\mathrm{n} 63$, at 230 .

177 Daniels $v$ Thompson, above n 112, at 78.

178 Ibid, at 68 .

179 Ibid, at 68.

180 Manning, above n 175, at 163.

181 Mary Michelle Gallant Money Laundering and the Proceeds of Crime: Economic Crime and Civil Remedies (Edward Elgar Publishing, Cheltenham, 2005) at 2.

182 Ibid, at 3. 
legislation, the Crown has the power to confiscate property "derived directly or indirectly" from human trafficking, ${ }^{183}$ or representing "the value of a respondent's unlawfully derived income". ${ }^{184}$ The Crown would thus be able to recover any benefit derived by a respondent "knowingly, directly or indirectly" from human trafficking. ${ }^{185}$ The legislation does not, however, entitle the victim to claim any confiscated assets. Thus, there is a tension between the statutory right of the Crown and any claim of the victim to account of profit. ${ }^{186}$ Generally, the courts should not interfere with the interventions of Parliament by extending common law principles. ${ }^{187}$ Arguably, the Crown's statutory right to the proceeds of crime should prevail and preclude any claim by the victim to an account of profit. ${ }^{188}$ In Attorney-General v Blake, Mr Blake's breach of contract also amounted to a serious statutory offence. ${ }^{189}$ If he had been able to be tried and convicted, it is unlikely that the Crown would have had an action for account of profit as his assets would have been susceptible to criminal confiscation orders. If a defendant's assets are confiscated, they can no longer be said to be "unjustly enriched". The essential foundation of account of profit is then missing. In principle, however, there is an objection to the State receiving money generated by the exploitation of the claimants.

\section{CONCLUSION}

Human traffickers realise huge profit with huge disregard for the human rights of their victims. Criminal punishment and proceeds of crime legislation may punish convicted traffickers. State funded compensation schemes and damages may compensate some of the harm caused to victims. But traditional remedies and punishment do not adequately vindicate the rights violated by the trafficking. It is hardly surprising that Treacy $\mathrm{J}$ sought to use exemplary damages to do justice on the facts.

Prevention of unjust enrichment is not, however, a proper basis for exemplary damages. It is the leading principle behind the rapidly evolving remedy of account of profit. Exemplary damages and account of profit may both have the effect of eliminating a defendant's gains in the commission of a wrong but they are very different remedies. Exemplary damages focus on the motives and conduct of the defendant. Their purpose is punishment and deterrence. Account of profit focuses on the

183 Criminal Proceeds (Recovery) Act 2009, s 7.

184 Ibid, s 3.

185 Ibid, s 7.

186 Gareth Jones "Stripping a Criminal of the Profits of Crime" (2000) Theoretical Inquiries in Law 70.

187 Chief Constable of Leicestershire v M, above n 176, at 23. See also Halifax Building Society v Thomas, above n 63, at 225 .

188 See Gareth Jones, above n 186, at 70 .

189 Official Secrets Act 1989 (UK), s 1(1). 
defendant's profits and gains. Its purpose is primarily to ensure that a person does not profit from their wrong.

To justify an account of profit for a tort, a claimant must have a legitimate interest in depriving the defendant of their gains and an entitlement to the gains themselves. The right to disgorgement will generally turn on the content of the right which has been violated and the nature of the interest protected by that right. The unlawful conspiracies to commit the torts of false representation, false imprisonment, battery, assault and harassment violated the victims' right to the inviolability of their person. The traffickers used the claimants as "instruments for their own profit". In principle, the victims have an entitlement to those assets over and above all third parties including the State.

There may be concern that accounting for the profits of sex trafficking might focus too much on the profit making and fail to adequately recognise the suffering of the victims, but it is submitted that it can serve as an important addition to other civil and criminal remedies and punishment. Present judicial opinion in New Zealand denies the compatibility of account of profit and compensatory or exemplary damages. However, in a case like Dulghieru, where there is little correlation between the harm suffered and the profits made, it is unclear that the awards need to be mutually exclusive. Similarly, if just stripping the profits made is not going to achieve the objectives of punishment and deterrence, it is unclear why exemplary damages should not be available to top up the award. Finally, unlike exemplary damages, account of profit does not raise concerns of double punishment where the defendant has been convicted, so it can sit alongside the criminal law, although it is likely that double counting concerns would preclude an account of profit where a defendant's assets are subject to criminal confiscation orders. 
